\title{
Terapi Aktivitas Kelompok Stimulasi Persepsi Pada Pasien Harga Diri Rendah
}

\section{Andika Rahmat Harefa1, Erma Fitria Samosir², Rut Imanita Sihombing³, Sarah Monica $^{4}$, Sry Nofita Sari Hutagalung ${ }^{5}$, Yuliana Romayanti ${ }^{6}$}

\section{Andikarahmat444harefa@gmail.com}

\begin{abstract}
Abstrak
Skizofrenia adalah suatu kondisi yang ada di semua budaya dan di semua budaya kelompok sosial ekonomi. Prevalensi skizofrenia diperkirakan sekitar $1 \%$ dari total populasi. Menunjukkan prevalensi gangguan mental emosional dengan gejala depresi dan kecemasan pada usia 15 tahun mencapai 14 juta orang. Angka ini setara dengan 6\% penduduk Indonesia. Harga diri rendah adalah disfungsi psikologis yang menyebar luas-terlepas dari masalah spesifik mereka, hampir semua pasien menyatakan bahwa mereka ingin memiliki harga diri yang lebih baik. Terapi Aktivitas Kelompok sangat efektif mengubah perilaku karena di dalam kelompok terjadi interaksi satu dengan yang lain dan saling mempengaruhi. Dalam kelompok akan terbentuk satu sistemsosial yang saling berinteraksi dan menjadi tempat Pasien berlatih perilaku baru yang adaptif untuk memperbaiki perilaku lama yang mal adaptif. Dalam pelaksanaan TAK jumlah Pasien terdiri dari 6 orang, dimana pesertanya 3 Laki-laki dan 3 Perempuan. Hasil dari kegiatan TAK Pasien mampu memperagakan/ mengekspresikan SP Harga Diri Rendah, dan mampu mengamati dengan baik jalan nya kegiatan TAK. Setelah mendapatkan terapi aktivitas kelompok stimulasi persepsi, pasien di Yayasan pemenang jiwa sumatera terjadi peningkatan pengetahuan, pemahaman tentang cara mengontrol emosi.
\end{abstract}

\section{BAB 1}




\section{PENDAHULUAN}

\subsection{Latar Belakang}

Skizofrenia adalah suatu kondisi yang ada di semua budaya dan di semua budaya kelompok sosial ekonomi. Prevalensi skizofrenia diperkirakan sekitar $1 \%$ dari total populasi. Menunjukkan prevalensi gangguan mental emosional dengan gejala depresi dan kecemasan pada usia 15 tahun mencapai 14 juta orang. Angka ini setara dengan 6\% penduduk Indonesia. Sedangkan prevalensi gangguan jiwa berat seperti skizofrenia mencapai 400 ribu. 6 hingga 7 dari 100 rumah tangga mengalami skizofrenia atau gangguan psikosis di Indonesia. Skizofrenia memiliki gejala positif dan gejala negatif. Gejala negatif termasuk harga diri rendah. Menurut Morton et al. harga diri yang rendah dapat menjadi konsekuensi dari gangguan kesehatan mental (seperti depresi, kecemasan dan kepanikan) atau dapat menjadi faktor kerentanan untuk berkembangnya masalah tersebut (Pardede, Keliat, \& Wardani, 2020).

Harga diri rendah yang tinggi digambarkan dari sifat individu yang memiliki perasaan penerimaan diri tanpa syarat, meskipun salah, kalah dan gagal, sebagai sifat yang berharga dan penting bagi dirinya sendiri. Individu yang memiliki perasaan tidak berharga, tidak berarti, dan harga diri rendah yang berkepanjangan akibat evaluasi negatif terhadap diri sendiri dan kemampuan sendiri merupakan gambaran seseorang yang memiliki harga diri rendah. Harga diri rendah adalah disfungsi psikologis yang menyebar luas - terlepas dari masalah spesifik mereka, hampir semua pasien menyatakan bahwa mereka ingin memiliki harga diri yang lebih baik. Jika kita hanya mengurangi harga diri rendah, banyak masalah psikologis akan berkurang atau hilang sama sekali. Harga diri merupakan komponen penting dari kesehatan psikologis. Banyak penelitian sebelumnya menunjukkan bahwa harga diri yang rendah sering kali menyertai gangguan kejiwaan (Pardede, dkk, 2020).

Terapi Aktivitas Kelompol (TAK): sosialisasi TAK adalah upaya memfasilitasi kemampuan sosialisasi sejumlah klien dengan masalah hubungan sosial. Salah 
satu gangguan hubungan sosial pada pasien gangguan jiwa adalah harga diri rendah. Terapi Aktivitas Kelompok yang bertujuan untuk megajarkan dan melatik pasien untuk beradaptasi dengan orang lain. Terapi Aktivitas Kelompok (TAK) stimulasi persepsi adalah terapi yang menggunakan aktivitas yang menggunakan aktivitas mempersepsikan berbagai stimulasi yang terkait dengan pengalaman dengan kehidupan untuk didiskusikan dalam kelompok. Hasil diskusi kelompok dapat berupa kesepakatan persepsi atau alternatif penyelesaian masalah (Widianti, Keliat \& Wardhani, 2017).

Beberapa penelitian mengenai pengaruh Terapi Aktivitas Kelompok terhadap Pasien dengan masalah keperawatan isolasi sosial seperti penelitian yang dilakukan oleh (Julianto, 2015) di rumah sakit jiwa Dr. Radjiman Wedioningrat Lawang, menunjukkan persentasi pelaksanaan yang memuaskan yaitu mencapai tingkat keberhasilan 90\% dimana mampu meningkatkan kemampuan pasien untuk berinteraksi sosial (Pribadi 2016) menunjukkan adanya pengaruh yang bermakna dari pelaksanaan Terapi Aktivitas Kelompok Sosialisasi. Keberhasilan ini dipengaruhi oleh beberapa faktor, salah satunya adalah peran perawat di rumah sakit tersebut yang turut membantu pelaksanaan TAK Sosialisasi yang senantiasa dikembangkan di dalam kegiatan sehari-hari melalui proses keperawatan. 


\subsection{Tujuan}

\subsubsection{Tujuan Umum}

Setelah mengikuti kegiatan ini Pasien dapat lebih menerapkan stategi pelaksanaan Harga diri rendah secara fisik dan sosial dalam mengontrol Harga diri rendah.

\subsubsection{Tujuan khusus}

1. Klien dapat mengidentifikasi pengalaman yang tidak menyenangkan

2. Klien dapat mengidentifikasi hal positif pada dirinya

3. Klien dapat memahami pentingnya menghargai orang lain

4. Klien dapat mengidentifikasi hal - hal positif orang lain

5. Klien dapat memberikan umpan balik positif kepada orang lain

6. Klien mengetahui pentingnya menetapkan tujuan hidup.

7. Klien menetapkan tujuan hidup yang realistis. 
BAB 2

\section{STANDART PELAKSANAAN TERAPI AKTIFITAS KELOMPOK STIMULASI PERSEPSI PADA PASIEN HARGA DIRI RENDAH KRONIS}

\subsection{Kriteria Anggota Kelompok}

2.1.1 Pasien harga diri rendah yang sudah mulai mampu bekerja sama dengan perawat.

2.1.2 Pasien harga diri rendah yang dapat berkomunikasi dengan perawat

2.1.3 Pasien harga diri rendah yang telah kooperatif.

\subsection{Proses Seleksi}

2.2.1 Mengobservasi pasien yang masuk kriteria.

2.2.2 Mengidentifikasi pasien yang masukkriteria.

2.2.3 Mengumpulkan pasien yang masuk kriteria.

2.2.4 Membuat kontrak dengan pasien yang setuju ikut TAK, meliputi: menjelaskan tujuan TAK pada pasien, rencana kegiatan kelompok, dan aturan main dalamkelompok.

\subsection{Uraian Struktur Kegiatan}

Hari/ Tanggal

Tempat Kegiatan

Waktu Kegiatan

Metode Kegiatan
: Selasa, 16 Maret 2021

: Halaman Yayasan Pemenang Jiwa

: Pukul 10.00 - 12.00 WIB

: Melatih kemampuan dengan SP 1-4

\subsection{Mekanisme Kegiatan}

\begin{tabular}{|l|l|l|l|}
\hline No & Waktu & Kegiatan Terapis & Kegiatan Peserta \\
\hline 1 & 10 menit & Perencanaan : & \\
& & a.Persiapan materi. & \\
& & b.Persiapan media/alat yang digunakan. & \\
& & $\begin{array}{l}\text { c.Setting tempat terapis dan peserta. } \\
\text { Pembagian tugas terapi. }\end{array}$ & \\
& & & \\
\hline
\end{tabular}




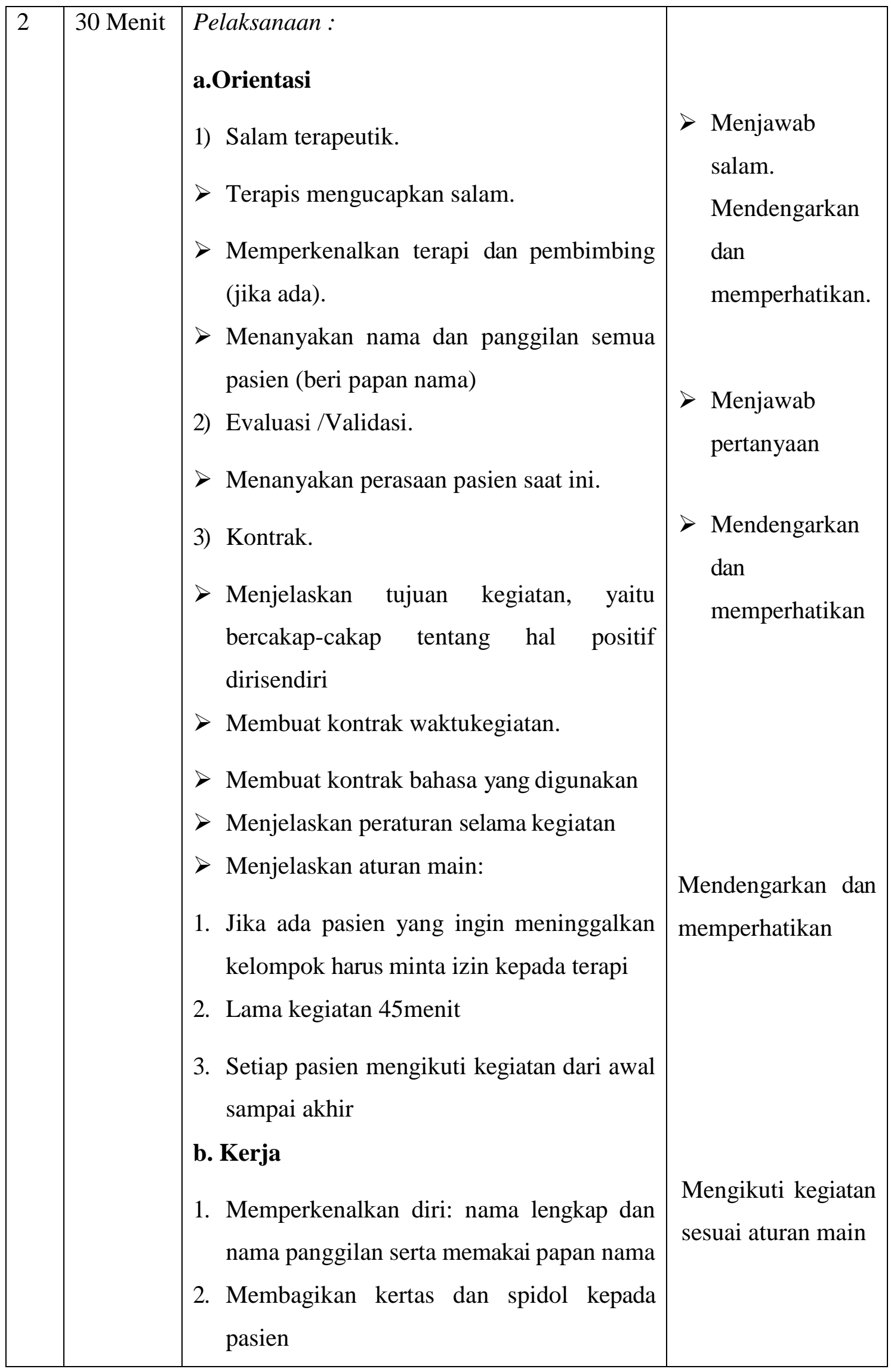




\begin{tabular}{|c|c|c|c|}
\hline & & $\begin{array}{l}\text { 3. Meminta tiap pasien menulis pengalaman } \\
\text { yang tidak menyenangkan } \\
\text { 4. Memberi pujian atas peran sertapasien } \\
\text { 5. Membagikan kertas yang kedua } \\
\text { 6. Meminta tiap pasien menulis hal positif } \\
\text { tentang diri sendiri: kemampuan yang } \\
\text { dimiliki, kegiatan yang biasa dilakukan di } \\
\text { rumah dan di rumahsakit } \\
\text { 7. Meminta pasien membacakan hal positif } \\
\text { yang sudah ditulis secara bergiliran sampai } \\
\text { semua pasien mendapatkan giliran } \\
\text { 8. Memberi pujian pada setiap peranserta } \\
\text { pasien }\end{array}$ & \\
\hline 3 & 10 Menit & $\begin{array}{l}\text { Terminiasi : } \\
\text { a. Evaluasi pencapaian tujuan. } \\
\text { 1) Menanyakan perasaan pasien } \\
\text { setelah mengikuti TAK } \\
\text { 2) Memberikan reinforcement positif atas } \\
\text { keberhasilan kelompok } \\
\text { b. Memberikan rencana tindakan lanjut } \\
\text { 1) Terapis meminta pasien menulis } \\
\text { hal positif lain yang belum tertulis } \\
\text { c. Kontrak TAK yang akandatang } \\
\text { 1) Menyepakati TAK yang akan datang, yaitu } \\
\text { melatih hal positif diri yang dapat } \\
\text { diterapkan di rumah sakit dan dirumah } \\
\text { menyepakati waktu dan tempat }\end{array}$ & $\begin{array}{l}\text { Mengungkapkan } \\
\text { pendapat. } \\
\text { Menyetujui } \\
\text { memberi } \\
\text { pendapat tentang } \\
\text { rencana } \\
\text { selanjutnya. }\end{array}$ \\
\hline
\end{tabular}

\subsection{Pengorganisasian Kelompok}


Leader : : Andika Rahmat Harefa

Co.Leader : Erma Fitri Samosir

Observer : Sry Nofita Sari Hutagalung

Fasilitator : Rut Imanita Sihombing

Sarah Monica

Yuliana Romayanti Manurung

\subsection{Perilaku Pemimpin / Terapis Yang Diharapkan}

2.6.1 Peran Leader.

2.6.1.1 Memimpin jalannya terapi aktifitas kelompok.

2.6.1.2 Merencanakan, mengontrol, dan mengatur jalannya terapi.

2.6.1.3 Menyampaikan materi sesuai tujuan TAK.

2.6.1.4 Memimpin diskusi kelompok.

2.6.2 Co.Leader :

1. Mendampingi Leader

2. Menjelaskan aturan permaian

3. Menyampaikan informasi dari fasilitator ke leader tentang aktivitas pasien

4. Mengingatkan leader jika kegiatan menyimpang dari perencanaan yang telah di buat

5. Mengambil alih posisi leader jika leader mengalami blocking dalam proses terapi

2.8.3 Peran Observer

1. Mencatat serta mengamati respon pasien (dicatat pada format yang tersedia).

2. Mengawasi jalannya aktifitas kelompok dari mulai persiapan, proses, hingga penutupan.

2.8.3 Peran Fasilitator.

1. Ikut serta dalam kegiatan kelompok. 
2. Memberikan stimulus dan motivator pada anggota kelompok untuk aktif mengikuti jalannya terapi.

2.8.4 Peran Anggota Kelompok.

1. Mengikuti Proses TAK dari awal sampai akhir

2. Mendengarkan dan memperhatikan pengarahan dari terapis

3. Menjawab pertanyaan bila ada pertanyaan dariterapis

\subsection{Media Dan Alat}

2.9.1 Spidol sebanyak jumlah pasien yang mengikuti TAK

2.9.2 Kertas putih HVS sebanyakdua kali jumlah pasien yang mengikuti TAK 2.9.3 Kertas origami sebanyakdua kali jumlahpasien

\subsection{Setting}

$\mathrm{Co}-\mathrm{L}$

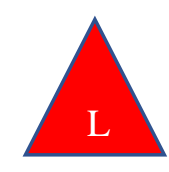

\section{$\mathrm{k}$}

$\mathrm{f}$

\section{k}

$\mathrm{k}$

Keterangan:

L : : Leader

CoL : Co-Leader 
Obs : Observer

F : Fasilitator

K : Pasien 


\section{BAB 3}

\section{EVALUASI}

\subsection{Hasil Pelaksanaan Kegiatan TAK}

Kegiatan TAK dilaksanakan pada 16 Maret 2021 jam 10.00 WIB. Kegiatan dilakukan di dalam halaman Yayasan pemenangan jiwa. Dalam pelaksanaan TAK, jumlah Pasien berjumlah 6 orang, peserta Laki-laki 3 orang dan perempuan 3 orang sesuai dengan proposal yang telah diajukan. Dalam terapi aktivitas kelompok perawat melakukan kontrak kepada pasien sehari sebelum TAK dilakukan. Mempersiapkan alat dan menyeting tempat dilakukan sebelum pasien datang di tempat pelaksanaan TAK. Suasana kegiatan TAK mulai dari awal hingga akhir acara berlangsung aman dan nyaman, Pasien sangat bersemangat. Pasien mampu memperagakan /mengekspresikan SP Harga Diri Rendah, dan Pasien mampu mengamati dengan baik jalan nya kegiatan TAK.

Sebelum TAK dilaksanakan, leader memperkenalkan diri kepada pasien dan leader memberikan kesempatan untuk co-leader, fasilitator dan observer untuk memperkenalkan diri kepada pasien dan memberikan pasien kesempatan untuk memperkenalkan dirinya masing-masing. Leader dan coleader saling bergantian menjelaskan peraturan terapi aktivitas kelompok, seperti bagiamana peraturan yang di buat saat terapi aktivitas kelompok dilaksanakan, durasi berjalannya terapi aktivitas kelompok dan memberikan infromasi kepada pasien bahwa perawat yang berada disebelah pasien sebagai fasilitator untuk membantu pasien selama berjalannya terapi aktivitas kelompok.

Dalam aktivitas kelompok, leader dan co-leader sudah melakukan tugasnya untuk menjelaskan jalannya terapi aktivitas kelompok dan memimpin jalannya terapi. Fasilitator sudah melakukan tugasnya untuk membantu pasien selama berjalannya terapi aktivitas kelompok. Observer telah melakukan tugasnya dengan mengamati jalannya terapi aktivitas kelompok apakah pasien mampu melakukan SP yang sudah ditentukan terapi.

\subsection{Respon Pasien}

Respon pasien saat diberikan terapi aktivitas kelompok yaitu : 
1. Mengindentifikasi kemampuan dan aspek positif yang dimiliki

Pasien mengatakan mampu melakukan kegiatan sesuai kemampuan yang pasien miliki, seperti ada yang suka membakar sampah, memotong rumput, membaca dan bernyanyi.

2. Menilai, menetapkan dan melatih kegiatan sesuai kemampuan yang dipilih 1

Pasien mengatakan dapat melakukan kegiatan yang mereka pilih seperti membakar sampah, memotong rumput, membaca dan bernyanyi.

3. Melatih kegiatan sesuai kemampuan yang dipilih 2

Pasien mengatakan mampu melakukan kegiatan yang mereka pilih 2 seperti membakar sampah, memotong rumput, membaca dan bernyanyi.

4. Melatih kegiatan sesuai kemampuan yang dipilih 3

Pasien mengatakan mampu melakukan kegiatan yang mereka pilih 3 seperti membakar sampah, memotong rumput, membaca dan bernyanyi. 


\section{BAB 4}

\section{PENUTUP}

\subsection{Kesimpulan}

Terapi Aktivitas Kelompok : Sosialisasi (TAKS) merupakan suatu rangkaian kegiatan yang sangat penting dilakukan untuk membantu dan memfasilitasi pasien HDR untuk mampu melatih kegiatan yang dimiliki sesuai kemampuan individu. Tujuan khusus TAKS, yaitu : mengindetifikasi kemampuan dan aspek positif yang dimiliki pasien, menilai, menentapkan, melatih kegiatan sesuai kemampuan yang dipilih 1, melatih kegiatan sesuai kemampuan yang dipilih 2, melatih kegiatan sesuai kemampuan yang dipilih 3, Harga diri rendah merupakan perasaan negatif terhadap dirinya sendiri, termasuk kehilangan kepercayaan diri, tidak berharga, tidak berguna, pesimis, tidak ada arapan dan putus asa. Tindakan yang dilakukan perawat dalam mengurangi resiko masalah yang terjadi pada kasus harga diri rendah salah satunya dengan melakukan komunikasi terapeutik, dampak yang terjadi jika tidak dilakukan komunikasi terapeutik maka dapat mengakibatkan gangguan interaksi sosial: menarik diri, perubahan penampilan peran, keputusasaan maupun munculnya perilaku kekerasan yang beresiko mencederai diri, orang lain dan lingkungan. Hal ini sesuai dengan apa yang telah dilakukan oleh penulis selama 3 hari yaitu mengajarkan SP1P, SP2P dan SP3P, dimana pasien sudahmenunjukkan hasil yang positif yaitu pasien sudah mulai mau berbicara, kontak mata bisa dipertahankan dan pasien sudah mau melakukan kegiatan mencuci piring setiap hari (Purwasih, \& Susilowati, 2016).

Dari hasil evaluasi ketika melakukan TAK isolasi social pasien mengikuti kegiatan dengan baik dan kondusif. Pasien juga mengikuti aturan permainan dan pada sesi 1 pasien juga mampu untuk meperkenalkan diri sendiri di hadapan orang lain. Pada sesi 2 pasien juga mampu berlatih berkenlan dengan orang lain dan teman dalam kelompok. Pada sesi 3, pasien juga terlihat mau berkonstribusi pada saat TAK berlangsung dan mampu menceritakan tentang perasaan menyenangkan mereka yang pernah terjadi pada diri mereka dulunya. Pasien merasa lega dan mendapatkan manfaat setelah mengikuti kegiatan TAK. 


\subsection{Saran}

Penulis menyarankan dalam pelaksanaan TAK tersebut masing-masing petugas pelaksana harus mampu melaksanakan perannya sebagai leader, co leader, fasilitator, dan observer. Sehingga, kegiatan TAK HDR dapat terlaksana sebagaimana yang diharapkan. Maka tujuan pembuatan proposal ini sebagai bentuk penyelesaian tugas ujian prektek keperawatan jiwa dapat tercapai. Demikianlah proposal ini kami buat atas perhatian dan kerjasama Bapak/Ibu kami ucapkan terimakasih. 
Kemenkes RI. (2019). Riset Kesehatan Dasar, RISKESDAS.Jakarta: KemenkesRI.https://databoks.katadata.co.id/datapublish/2019/10/08/perseba ran-prevalensi-skizofreniapsikosis-di-indonesia\#

Pardede, J. A., \& Laia, B. (2020). Decreasing Symptoms of Risk of Violent Behavior in Schizophrenia Patients Through Group Activity Therapy. Jurnal Ilmu Keperawatan Jiwa, 3 (3), 291-300. http://journal.ppnijateng.org/index.php/jikj/article/view/621/338

Pardede, J. A., Keliat, B. A., \& Wardani, I. Y. (2020). The Symptoms of Low SelfEsteem Decline after Being Given Acceptance and Commitment Therapy. Adv Practice Nurs, 5, 170. doi: 10.37421/apn.2020.05.170

Pitayanti, A., \& Hartono, A. (2020). Sosialisasi Penyakit Skizofrenia Dalam Rangka Mengurangi Stigma Negatif Warga di Desa Tambakmas KebonsariMadiun. Journal of Community Engagement in Health,3(2), 300-303. https://jceh.org/index.php/JCEH/article/view/83/78

Rokhimmah, Y., \& Rahayu, D. A. (2020). Penurunan Harga Diri Rendah dengan menggunakan Penerapan Terapi Okupasi (Berkebun). Ners Muda, 1(1), 18. https://doi.org/10.26714/nm.v1i1.5493

Sitanggang, R., Pardede, J. A., Damanik, R. K., \& Simanullang, R. H. (2021). The Effect Of Cognitive Therapy On Changes In Self-Esteem On Schizophrenia Patients. European Journal of Molecular \& Clinical Medicine, 7(11), 26962701.

Suwarni, S., \& Rahayu, D. A. (2020). Peningkatan Kemampuan Interaksi Pada Pasien Isolasi Sosial Dengan Penerapan Terapi Aktivitas Kelompok Sosialisasi Sesi 1-3. Ners Muda, 1(1), 11-17.

Wandono, W. A., \& Arum Pratiwi, S. (2017). Upaya peningkatan harga diri rendah pada pasien depresi (Doctoral dissertation, Universitas Muhammadiyah Surakarta).http://eprints.ums.ac.id/id/eprint/52383

WHO, (2019). Schizophrenia. Retrieved from. https://www.who.int/newsroom/fact-sheets/\%20detail/schizophrenia

Widianti, E., Keliat, B. A., \& Wardhani, I. Y. (2017). Aplikasi Terapi Spesialis Keperawatan Jiwa pada Pasien Skizofrenia dengan Harga Diri Rendah Kronis di RSMM Jawa Barat. Jurnal Pendidikan Keperawatan Indonesia, 3(1), 8399. https://jurnal.unimus.ac.id/index.php/fikkes/article/view/244 